\title{
Inhabiting the EdgeS: Transtextuality and Subduction
}

\section{Marta Dvorak}

\section{(2) OpenEdition \\ 1 Journals}

Electronic version

URL: https://journals.openedition.org/ces/7845

DOI: $10.4000 /$ ces.7845

ISSN: 2534-6695

Publisher

SEPC (Société d'études des pays du Commonwealth)

\section{Printed version}

Date of publication: 1 September 2011

Number of pages: 11-23

ISSN: 2270-0633

\section{Electronic reference}

Marta Dvorak, "Inhabiting the EdgeS: Transtextuality and Subduction", Commonwealth Essays and Studies [Online], 34.1 | 2011, Online since 16 November 2021, connection on 01 December 2021. URL: http://journals.openedition.org/ces/7845 ; DOI: https://doi.org/10.4000/ces.7845

\section{(c)}

Commonwealth Essays and Studies is licensed under a Licence Creative Commons Attribution - Pas d'Utilisation Commerciale - Pas de Modification 4.0 International. 


\section{Inhabiting the EdgeS: Transtextuality and Subduction}

This investigation of global dialogism engages with the transcultural writing and reading practices on the march well before our current post-colonial period. I explore how the environment of social heteroglossia found in imperial spaces catalyzes a process of penetration and stratification which explodes the ossified deposits of closed socio-linguistic systems in which literary language is often rooted. The forms of cultural and literary subduction discussed in a spectrum of works by writers ranging from Tagore to Janet Frame raise the spectre of an erosion of contexts, but hold out the promise of construction which is involved in tectonic processes.

The Africa Trilogy was one of the most successful as well as original theatrical events at Toronto's annual arts festival, Luminato, in June 2010. The small Toronto-based company, Volcano Theatre, was commissioned to assemble a trilogy of short plays to explore a complex, protean subject: Africa and its relations with the West. Playwrights and directors from three continents contributed to the trilogy. Shine Your Eye, written by Kenyan Binyanvanga and directed by Volcano's Ross Manson, is set in contemporary axiologically-fraught Nigeria. Peggy Pickit Sees the Face of God, written by the German playwright Roland Schimmelpfennig and directed by Liesl Tommy, takes as its setting an unsettling homecoming party for a couple who has spent six years in Africa as part of a medical aid team. The clever writing and directing, deploying multimedia techniques such as freeze-frame action, video, overlapping, and reprise, clearly borrow from Edward Albee's landmark play of 1962, Who's Afraid of Virginia Woolf (Albee's play, like its alternative theatre venue, Off-Broadway, significantly having gone mainstream) and takes it global in both content and form. In 2011 Luminato presented the world premiere of an ambitious new adaptation of an ancient literary classic, created by Tim Supple, who in 2003 had adapted and directed Rushdie's Midnight's Children for the Royal Shakespeare Company, and then in 2008 staged the unorthodox South Asian version of A Midsummer Night's Dream with a multilingual, multiethnic Indian cast which illuminated the play by underscoring the different ways in which Shakespeare "speaks" to, throws into relief, and often even merges with their own worldviews. 'One Thousand and One Nights was a two-part, equally multilingual epic with a cast of twenty-five from the Arabic world.

\section{Global dialogism}

Such cultural events are redolent with global dialogism. No culture is full unto itself, no culture is plainly plenitudinous, Homi Bhabha declared to Jonathan Rutherford over a decade ago, arguing that each culture's symbol-forming activity and

1. One can also call up Québec director Robert Lepage's groundbreaking 1989 bilingual production of Romeo and Juliet in the anglophone Canadian prairies, in which Romeo and the Montagues used the original Shakespeare text while Juliet and the Capulets spoke in $16^{\text {th }}$-century French (thus superimposing a New World historico-political layer of fraught English-French colonial relations onto the Renaissance cultural context). 
interpellation in the process of representation and meaning-making is in translational relations with other cultures. Also over a decade or a decade and a half ago, other critics and cultural theorists like Elleke Boehmer, Derek Walcott, Michael Dash, and Vinay Dharwadker were already acknowledging that the dynamic mixing of languages, forms, and styles functioning as a catalysis of creation was a global phenomenon, and that publishers were consequently boosting their transnational distribution to reach global audiences (Dharwadker 105-8). The critics linked the poetics of creolization involving linguistic and cultural imitation and reconfiguration to postcolonial concerns and praxis, but also to postmodernism's suspicion of "sacred origins and pure beginnings" and its preoccupation with displacement and incompleteness (Dash 52). While such transnational interplay in the $\operatorname{arts}^{2}$ is evident in the post-colonial era, ${ }^{3}$ it is indeed doubtful that its origins can be entirely imputed to the paradigms of $20^{\text {th }}$ century decolonization, migration, or even the global marketing of the post-colonial exotic which Graham Huggan has more recently investigated. I propose to reach beyond and engage with the transcultural writing and reading practices on the march well before our current post-colonial period. I wish to explore how the environment of social heteroglossia found in imperial spaces, an environment in which different language consciousnesses with their discrete world views interrelate, catalyzes a process of penetration and stratification which explodes the ossified deposits of closed socio-linguistic systems in which literary language is often rooted. Grounding my analysis in Bakhtinian theories of linguistic heteroglossia, I want to move beyond notions of submission, namely the monovalent submission of one language and its accompanying culture and belief system to a newly dominant language and its cultural baggage, and to explore the complex way in which the alien other-languagedness of English has rather been seized, appropriated, or even expropriated by indigenous writers to fissure the sharply delineated boundaries of their own literary language.

It can be useful to recall that English itself is a hybrid product catalyzed by conquest, having undergone the subduction and stratifying saturation of NormanFrench after 1066. At the risk of going against the grain of influential post-colonial currents, I shall show that many a writer on the Indian subcontinent embraced the English language not so much for its audience-reaching potential as for its dialogical elasticity. I shall also argue that the expropriation involved a connection between language and genre. English began to be adopted as a literary language in South Asia in the $19^{\text {th }}$ century. So did the relatively new, imported genre of the European novel. The two did not systematically overlap in the manner of tectonic processes, for novels were produced in Bengali and other vernacular (rather than sacred) languages such as Malayalam and Telegu as well as Hindi. But both were embraced precisely because they allowed these latecomers to prose the digressions and convolutions which the entrenched literary language and generic conventions resisted.

2. Another creation by Lepage deserves mentioning here, namely his work-in-progress Tectonic Plates, a metaphor for cultures drifting, colliding, and overlapping, involving a Québécois hippy travelling in Italy, a Welsh concert pianist, a New York radio talk show host, and a mythical Scottish Highlander. First performed in Toronto in 1988, the work went to Glasgow in 1990 and underwent tectonic collaboration and improvisation with Glaswegian performers, which produced new, intercultural scenes.

3. I adhere to the useful typographical distinction many critics make and thus use the term "post-colonial" to designate the post-independence period of former colonies, while "postcolonial" denotes the body of literature and theory that spills over chronological boundaries. 
The emergence of cultural and ideological interstices is particularly discernible in spaces such as Northern India where Turks, Mongols, and Persians had always intermingled and conjoined, in a process reflecting the collapse and rise of multiple, overlapping empires. ${ }^{4}$ Indian writers are thus well positioned to decentre the postcolonial commonplace investigating British imperial and post-imperial space and to substitute for the centre/edges paradigm a vision of flux. Their more distanced, syncretic vantage point contends with the cyclic nature of history and the building and crumbling of empires which readers also find in Western reflections on dying world orders, from Anton Chekhov's The Cherry Orchard to T. S. Eliot's Four Quartets, William Faulkner's Light in August, and Derek Walcott's "Ruins of a Great House." Indian fiction in English can thus be considered exemplary of global literature which can be collocated within cross-cultural as well as culture-specific frameworks, and which undermines monologic axiologies by multiplying the sources from which it freely and shape-shiftingly borrows. The Indian writers I focus on chose or have chosen to write in English when conditions were often inimical to such an adherence, for as Amit Chaudhuri observes in the introduction to his anthology of modern Indian fiction, "What is perceived to be, or even constructed as, standard English is seen to be linked to an alien sensibility and to the verbal traditions of colonialism" and thus less compatible with the hybrid, multilingual nature of Indian consciousness. Chaudhuri judiciously points out, however, that hybridity "need not be worn like national costume" (xxvi).

\section{Wars over a spoken tongue prose: inter-peripheral comparisons}

Why should Anita Desai declare in the early 1980s that she was "very glad to be writing in a language as rich, as flexible, supple, adaptable, varied and vital as English"? ("The Indian Writer's Problems" 1) Over a century earlier, further back than the British Raj, why should the renowned Bengali poet Michael Madhusudan Dutt (1824-1873) declare as early as 1854 in his essay "The Anglo-Saxon and the Hindu," "I love the language of the Anglo-Saxon. Yes - love the language - the glorious language of the Anglo-Saxon!" (Chaudhuri 6, original stress). An explanation is subsequently offered indirectly, through a combination of personification and extended simile. What Dutt values in the English language is that "It laughs at the limit which the tyrant Grammar would set to it," and that "It flows on like a glorious, a broad river, and in its royal mood, it does not despise the tribute waters which a thousand streams bring to it" (7). The geographical analogy configures a reversal of the stereotype of the English language as a subjugating force, recalling rather that it has undergone and been nourished by successive waves of occupation and conquest, from the Saxons and Danes to the Normans, which have enriched it with a complex verbal-ideological history and heteroglossic dynamics. Dutt exults, "There is no one to say to it - thus far shalt thou go, and no farther! Give me, I say, the beautiful language of the Anglo-Saxon" (7). Dutt's celebration paves the way for Salman Rushdie's statement a century later that "to conquer English is to complete the process of

4. One can notably call up the Moghul Emperor whose reign strikingly coincided with that of Elizabeth I: the multireligious Akbar, son of a Sunni father and a Shia mother who took a Hindu wife, Jodhaa, daughter of the Rajput Prince of Amer (near today's Jaipur), and allowed her to keep her religion. 
making ourselves free" (Imaginary Homelands 17) linguistically as well as politically. ${ }^{5}$ What especially appealed to Dutt, and then Rushdie subsequently, is apparently the incremental language-bending the pliable system offers, absorbing and passing on portmanteau neologisms from Lewis Carroll's chortle to Rushdie's chutnification. In other words, what appeals is the absence of regimentation encountered in single, closed language systems which privilege unity and purity.

That Dutt should have regarded his own mother tongue, Bengali, as a confining system from which English provided an opening is corroborated if we look at how another major figure of the Bengal Renaissance, Rabindranath Tagore (1861-1941), steered and tacked between poetry and prose, Bengali and English, and classical and modern registers, all of which amounted to choosing between a stilted book language that had become ossified over the centuries (sadhubhasha) and the colloquial living language of contemporary everyday speech (chalitbhasha). ${ }^{6}$ As Amit Chaudhuri points out, "the hegemonies Bengali writers were concerned with subverting [...] had less to do with Empire, the colonizer, or the English language" than with "traditions and hierarchies embedded in the Bengali language itself" (106). The older Tagore rebelled against the normative linguistic and generic stratifications which were coterminous, for traditional verse was by definition (and has always been) more closely shackled by the sclerotic deposits of convention than the more recent, imported, hybrid genre of prose. He initially introduced spoken language in dialogue all the while keeping the classic language for the narration, a compromise which anticipated the mixed diction practices of Caribbean writers such as V. S. Naipaul, tending to deploy standard English - deemed elegant - for the narratorial voice and to keep the local idiolects deemed vulgar - for the direct speech of the characters, while in other writings such as Sam Selvon's the vernacular began to invade the narration itself ("The Cricket Match," 1957).

The Missing Links in these stylistic wars over a spoken-tongue prose linked to notions of identity and nationhood and stretching from the Indian subcontinent and Europe to the West Indies may be exemplified by the figures of Tagore in the East and his admirers Ezra Pound and W. B. Yeats in the West. Modernism was espousing common language. This involved rehabilitating the ordinary as appropriate subject matter and vocabulary for even poetry (for instance T. S. Eliot's chimney pots, vacant lots, newspapers, and window-blinds in "Preludes" or his factory and by-pass, figures of mass production and mass transport, in "East Coker"). But also the manner in which Modernists like Pound, Ernest Hemingway, and John Dos Passos were

5. Geetha Ganapathy-Doré points out the discrepancy between such a stance and that of certain Caribbean writers such as George Lamming's. She does not hesitate to pair Rushdie with Shakespeare in their manner of amplifying and developing "the flexibility of the English language and its potential for concrete imagery" by freely resorting to foreign loan-words, portmanteau words, neologisms, and puns, and observes that both "draw from the literary and vulgar varieties of English" (20).

6. An analogy closer to home for today's Western audiences and allowing them a clearer picture of the friction might be between sadbubhasha (the chaste or classic language) with literary French and its mandatory deployment of the aoristic, completive passé simple, which, like sadhu, cohabits uneasily with colloquial spoken French which wields the ongoing passé composé.

7. The divorce between literary language and the language in people's mouths has been extreme even in $20^{\text {th }}$ century Europe. We tend to forget that modernist writers like Franz Kafka continued to write and publish in German, not Czech, because after centuries of Austrian political and cultural domination no work written in the national language would be attributed the stamp of serious literature (see Kafka's novella "The Metamorphosis"). 
imposing an idiomatic North American English in place of the high style still required by standard literary decorum. Another identifiable connection is Ireland's sense of place and the turn of the century Celtic Twilight or Irish Literary Revival, which created subsequent shock waves in the analogously insular and colonised spaces of the Caribbean. Yeats is a key piece in the global jigsaw puzzle reconciling contemporary reality, writerly trans-lation/transmutation, and readerly recognition. The author of Catbleen ni Houlihan (1902) and founder of the Irish National Theatre Company admired Tagore's early writing, notably the Gitanjali prose poems which Tagore had auto-translated, or rather re-composed, or even re-incarnated. As Samuel Beckett ${ }^{8}$ would go on to do with his frictional auto-translations and fraught tradaptations, Tagore confessed to wishing to "rekindle" his poems "through the medium of a foreign language" (Letter 65, 117). Yeats lightly edited the poems and had them published, garnering for the Bengali writer the Nobel Prize for Literature (1913), ironically a decade before Yeats himself was awarded the same prize. What arguably pleased the Irish poet in Tagore's English recasting of Gitanjali was the otherlanguagedness flavour which Beckett would go on to pursue, ${ }^{10}$ and its successful effect of stretching and deforming the literary language. This was precisely what Yeats and his fellow Irish playwright John Millington Synge were undertaking to do by deploying the rhythms, syntax, and musical intonations of Irish speech ${ }^{11}$ complete with unfamiliar, unglossed local words in, for example, Synge's Riders to the Sea (1904) and The Playboy of the Western World (1907), whose first performance caused an uproar at the Abbey Theatre in Dublin. Synge, too, is an important piece in our interlocking global jigsaw. Caribbean poet and playwright Derek Walcott ${ }^{12}$ has freely proclaimed Synge's Riders to the Sea to be his model, an intertext as well as a hypotext, for his first folkplay, The Sea at Dauphin (1957). ${ }^{13}$ Adhering to the linguistic, dialectological torsions of his fellow Modernists, Walcott's writing of (re)locatedness involves not only the use of Antillean idiom, but also the transposition and transliteration provided by a multilingual, bi- or multi-cultural society. Michael Malouf's study of how Walcott's dissimilation of Riders to the Sea resides in the way it transmutes an Irish nationalist aesthetics to a Caribbean federationist aesthetics has wider reverberations. Its interperipheral comparisons engage a reflection on cross-cultural encounters on the

8. Interestingly, Beckett (another Nobel Prize recipient) was an avowed admirer of Kafka.

9. Murphy and Watt, for instance, were published in English in 1938 and 1953, rewritten and published in French in 1947 and 1968 respectively.

10. Beckett then pushed his linguistic experiments in Shklovski's ostrenie to an extreme by writing his trilogy in French first. Molloy, Malone meurt, and L'Innomable are literary-verbal performances, even performative acts of free will involving choosing a language the better to violate it - the violation of the acquired cognitive language increased exponentially when translated (back) almost literally into the mother tongue made strange (Molloy, Malone Dies, The Unnamable).

11. With respect to standard English, this notably involves inversion and dislocation, but especially the paratactic elision of relative pronouns and conjunctions, auxiliaries, and even the verb "to be." The overall effect is that of paring away the taxemes (serving to indicate relations between syntagms) and trimming the language down to its vital essentials - dynamic verbs and nouns.

12. Walcott was awarded the Nobel Prize for Literature in 1992.

13. Walcott declared in an interview that he embraced such models because what he had "was the same thing Synge had: a totally new language, a totally new set of rhythms, and a totally new people, in a sense" ("Conversation with Derek Walcott," qtd. in Fumagalli xviii). See also Walcott's discussion of influences in "Derek Walcott and E.A. Markham Read and Talk," as well as my analysis of the propinquity - in relationship if not in place - between Walcott's melding of sound and icon and the practices of performative sound poets in Canada (Dvorak, "Troping the Voice-Print in Walcott's Rhetoric of Performance"). 
margins of dominant modernisms not so much in terms of identity as in terms of recognition and collocation.

I have been demonstrating the malleable English language's ability to bridge cultural divides. The plasticity which allows it to take on the rhythms, say, of South India's Kannada vernacular in Raja Rao's Kanthapura (1939), or, in Narayan's terms, to "take on the tint of any country" (Walsh 7, my stress), has been addressed by Feroza Jussawalla. Jussawala has identified nativization strategies used by Rao, Anand, and Narayan (but which resonate with my discussion of Synge and Walcott and are transferable to, say, a Nigerian writer such as Chinua Achebe [Things Fall Apart, 1958] or a Canadian writer of Italian descent such as Nino Ricci [Lives of the Saints, 1990, set partly in Italy]). Such strategies range from interpolating indigenous terms or their literal translations (calquing) to "syntax whose disconcerting simplicity [a metropolitan English] readership finds alien" (Jussawalla 79). In fact, even a native Anglophone, also exemplary of peripheral modernisms, namely New Zealand novelist, poet, and short story writer Janet Frame, ${ }^{14}$ initially outraged critics, fellow writers, and general readers by her style consisting of "simple statements, endlessly joined by a chant of 'ands'," and of dialogue "all run together into long paragraphs, and plenty of New Zealand slang and colloquialisms" (anonymous 1951 Christchurch Press review of The Lagoon: Stories, qtd. in King 108). Interestingly, the very qualities which critics disparaged in Frame's writing were those which Bakhtin has identified as the key dialogical qualities of novelizing. The Russian formalist has judiciously defined the novel as "a diversity of social speech types (sometimes even diversity of languages) and a diversity of individual voices, artistically organized." "Frame's style is exemplary of the stratification of language into the disparate social dialects, professional jargons, generational, tendentious, and authoritative languages of interest groups, each with its own formulae, which Bakhtin argues had never been combined before the unfurling of the hybrid genre of the novel. The everyday-conversational style which the late Modernist from the antipodean periphery (like her early Modernist predecessors) adopted in her first short fiction collection moreover corresponds to one of the five basic types of compositional-stylistic unities into which Bakhtin breaks down the novelistic whole," namely skar, the Russian term for textualized orality, or "the stylization of the various forms of oral everyday narration" (262). The features that make Frame's writing sound like spontaneous speech are the repetition, colloquialisms, stereotyped sentences, and parataxis - the extremely simplified syntax consisting of placing one clause after another with no connectors except for a string of "ands." I have discussed how Samuel Beckett unsettled the stock phrases of socioideological language shot through with the intentions and accents of countless other speakers by approaching one language through another (writing in a learned language rather than the mother tongue, then transliterating back into a deliberately fraught English). Frame went about the war on trite language from the opposite pole of the

14. Frame was awarded the Commonwealth Writers' Prize in 1989.

15. The Dialogical Imagination 262. Unless otherwise specified, further allusions to Bakhtin refer to this collection of essays.

16. Besides the stylization of the forms of oral everyday narration, the others are: direct authorial narration; the stylistically individualized speech of characters; the stylization of semiliterary (written) forms of everyday narration (diary/letter); literary but extra-artistic authorial speech (moral, philosophical, or scientific statements, descriptions, memoranda etc; Bakhtin 262). 
axis. She took the words in people's mouths and injected their everydayconversational language into the still sharply defined borders of written language, and on the whole the New Zealand literary establishment did not like it. ${ }^{17}$ It went against the grain of the coherent, unified segments of narrative at the heart of the realist aesthetic which in the early 1950s was still dominant in societies inhabiting the edges, and which was entrenched in the notions of an abstract-linguistic unity of (high) literary language. "The Day of the Sheep" is exemplary of Frame's mercurial shifts in voice and point of view, flitting from dialogue to inner focalization inhabited by the speech of others. ${ }^{18}$ Asked by his wife Nance if his bringing home handkerchiefs forgotten in the pockets of coats left at his Dye Works might amount to stealing, Tom's voice answers, then with nary a transition, mutates into Nance's interior monologue, indissolubly mingled with what Bakhtin terms "common language" (301):

-Stealing my foot, I tell you I've worked two years without a holiday. You see? Tom striving for his rights and getting them even if they turn out to be only a small anonymous pile of men's handkerchiefs, but life is funny and people are funny, laugh and the world laughs with you. (Frame 57)

The author puts the concluding common adage into the focalizer's mouth/thoughts precisely to underscore "the common view," the local society's normative verbal approach to people and things, "the going point of view and the going value" (301-2, original stresses), as conveniently flexible as language is in the polysemic word "funny" (strange/comic). Elsewhere, Frame stylizes and diffracts the platitudes of pietism. A stream of visitors and corresponding run-on sentences console a mother for the death of a daughter: "But it's all for the best and you have Wonderful Faith Mrs. Todd, she's happier in another sphere, you wouldn't have wished it otherwise, and you've got her photo, it's always nice to have their photos" (Frame 30). These affectedly sanctimonious phrases denying the grief, anger, fear, and existential doubt which thinking, perceiving humans encounter in a close brush with mortality are hollow, it is suggested through the distancing device of emphatic capitalization. And also through the flippant equation made between a picture and a child. The equal value given the picture is part of the going point of view and the going value of the social group from which the authorial consciousness distances itself and us. The axiological gap engineered by the verbal refraction is thus a satirical one challenging the authoritative, monolithic thought potentially concealed in an apparent multiplicity of social voices which the author ventriloquates.

Frame's disruption of a doctrinal belief-system through the spoken tongue disruption of local linguistic traditions, in other words her speaking and acting through language, underscores once more the homology between poetics and life, between stylistic form and the socio-ideological cultural horizons which open up behind the heteroglot language. The written text, too, is a form of dialogue, a "verbal performance in print" (Bakhtin, "Marxism and the Philosophy of Language" 939, original stress)

17. While a literary award for her newly published Lagoon story collection did raise interest in her writing and even notoriously save her from being lobotomized, a predilection for realist writing remained as strong in New Zealand as in Australia, where her fellow modernist Patrick White, who went on to garner the Nobel Prize, encountered negative responses to The Tree of Man (1955), dubbed "pretentious and illiterate verbal sludge" (Goldsworthy 126).

18. See my essay "Frame-Breaking: 'neither separate nor complete nor important'," in the special issue of Commonwealth Essays and Studies devoted to Janet Frame's short fiction. 
involving three coordinates. As Julia Kristeva has argued in Desire in Language: A Semiotic Approach to Literature and Art, the writing subject engages syntagmatically with the response of the projected audience, all the while the word in the text is paradigmatically oriented towards a dialogue with exterior texts, namely a diachronic or synchronic literary corpus which melds with a broader cultural context. A shift back to Indian fiction in English will now demonstrate how the print performance addresses, anticipates, and integrates the very responsiveness of the receiver which it aims to engineer.

\section{Construction and erosion}

The concluding part of this paper will address how the writing subject, disembodied yet rooted in personal authorial experience, interrelates with the extratextual reality he/she shares with a protean addressee, shifting and merging between local and global audiences. The mixed-race, Indo-Irish novelist and essayist, Aubrey Menen (1912-1989), bridges and mediates between London (where he was born) and Trivandrum, in Kerala (where he died), underscoring cultural convergences by stressing cultural divides. In his satirical, autobiographical investigation of identity construction, Dead Man in the Silver Market (1954), Menen defamiliarizes by inverting traditional Orientalist discourse on social issues ranging from the petty to the grand, from plumbing to racism. The boy of twelve is summoned for the first time by his paternal grandmother to Malabar, whose traditional matrilinear basis of social organization promises to upset the patriarchal assumptions which the Englisheducated child has absorbed and brought with him. The grandmother is a mighty dowager from the Nayar warrior-ruler-caste who demonstrates her female power by receiving him bare-breasted, in other words formally baring the attributes which only a flirt would coquettishly cover. As the eye and voice of eastern doxa, she reflects and deflects a series of stereotypes corresponding to entrenched Western prejudices, by objecting to the dirty English, their bestial manners, and their barbaric customs. She scornfully dismisses the "backwardness of the white man's bathroom" in which "you sit in dirty water like a buffalo" (Menem 352). She is not surprised that the English should eat ham and beef, for she admits in an eloquent analogy that after all the outcastes who clean the latrines also eat anything. What she expresses particular disgust at is the European shamelessness regarding the intimate act of eating: rather than secluding themselves, the English "watch each other thrust food into their mouths, masticate, and swallow" (350). "She expresses surprise that in England "a woman could have more than one husband" (350) and accuses the English of neglecting their children by not marrying them safely off when young to a carefully chosen partner so as to discourage subsequent lewdness and promiscuity.

19. A cinematic analogy comes to mind: Le Fantôme de la liberté [The Phantom of Liberty or The Specter of Freedom], a nouvelle vague film directed by Luis Bunuel (1974), which in a carnivalesque manner calls attention to the intimate nature of ingestion by inverting it with its corollary, that other end of the digestive process, defecation. Bunuel upsets the elegant ritual of the bourgeois dinner party at which one leaves the table discreetly to relieve oneself in the toilet by replacing it with a party at which the guests engage in polite conversation while defecating around a table, from which they sneak away in turns to bolt down a bite of food. By reversing the object of the ritual and presenting dining as the shameful act to be performed in private, Bunuel underscores our animal nature, and, like Menen and his Malabar lens and mouthpiece, simultaneously challenges Western notions of propriety which permit spectacle to invade the private sphere. 
Menen's process of estranging, of transmuting the familiar into the unhomely both individual and cultural - unhouses the Western subject from his or her former groundings, and ironically operates from those very groundings. The civilization of ancient Greece and the republic of Rome had always been models for England (and the US), and an acquaintance with the classics signified one's appurtenance to the powerful elite. Menen's authorial voice interestingly overcodes the grandmother's so as to buttress the Indian vantage point by identifying its similarities with the venerated values of Rome and its historico-mythical heroes.

The great majority of civilized peoples have always agreed with her. Romance and love and such things were, in antiquity, things for slaves. Respectable families arranged their marriages as my grandmother arranged those of her offspring. To take a single example, my grandmother and Brutus would fully have understood each other. She felt hurt that she had not been consulted over my father's marriage [to a white woman]: while among the many sidelights that we have on that honourable man who assassinated Julius Caesar is a letter in which he complains at being left out of the bargaining that went on during the betrothal of "my dear little Attica," who was nine years old. (352-3)

Adding to the irony is Menen's cunning demonstration of his familiarity with that other classic, even iconic, text, Shakespeare's Julius Caesar, which in turn, through the alluded-to speech by Marc Antony, suggests the slippery nature of virtus/virtue and values, of civilised and barbarous behaviour.

In the same dynamic of inversion, the grandmother's ideological views on the Occident are essentialist. She makes high-handed statements about the epistemological and ontological inferiority of the English who "still went about naked" when her "superior race" (354 and 352 respectively) had already written down its sacred texts in books. Her authoritative, reductive stance, based on no first-hand knowledge, reflects and refracts the systematic judgments regarding the East "shot through with doctrines of European superiority" which Edward Said identified in Orientalism (8): "She had never met the English but she knew all about them. She knew they were tall, fair, given to strong drink, good soldiers and that they had conquered her native country. She also knew that they were incurably dirty in their personal habits" (349, stress added). The Nayar matron's description comprises sweeping generalizations despite, or rather through, the precise list of specific attribute, thus corresponding to Said's denunciation of Orientalist distortion when "either too general or too specific a level of description is maintained systematically" (8), in particular when the atomization fails to offer any "general lines of force informing the field" (8-9). Menen augments the diffraction through another classical analogy equating the English with the barbarian hordes that destroyed Roman civilization, an analogy which both deviates from and breaks up the Western ordered worldview: "She respected them but wished they would keep their distance. It was very much the way that a Roman matron looked upon the Goths" (Menen 349). Just as a European or American studying the Orient in Said's terms "comes up against the Orient as a European or American first, as an individual second" (11), so too does Menen show that because of her caste/class, social position, culture, and belief system, his grandmother cannot help but come up against the Occident - in the shape of the unclean white daughter-in-law who defiles her house - as an Indian first, an individual second. Paradoxically, this does not drive East and West farther apart, but brings 
them closer together to form new cartographies. The author (provocatively) confesses, "Much as she looked down on the English, I think that had she met some of them, had she overcome her well-bred fastidiousness and actually mixed with them, she would have found she and they had much in common. Her riding passion, like theirs, was racial pride" (352). He then deploys a more overt geopolitical rapprochement between East and West with respect to the power relations between what Stendhal called the red and the black, between army and church, Kshatriya and Brahmin. Although Brahmins are officially the highest, priestly caste, members of the warriorruler castes like the Kerala grandmother treat them like domestic chaplains. Priests were "expected to make themselves agreeable, in return for which they were regularly fed" (354). Moreover, with the temples being on family property, it was the powerful older women in Malabar who distributed the "livings," astonishingly like Jane Austen's ferocious snob, Lady Catherine de Bourgh, in Pride and Prejudice, the autocratic twin of the benevolent Colonel Brandon in Austen's Sense and Sensibility. Menen acknowledges that the Anglican Settlement in England was a more elaborate affair, but stresses the "striking resemblances" (354) in the empirical power relations of modern and ancient political-intellectual establishments alike.

In what amounts to meta-narratives about his paternal grandmother, the mixedrace, migrant, multicultural author shows how localized forms of knowledge interlock with global forms in a dialogical process much like the living, developing English language and the prose genre of the novel, epitomes of absorbability. By mentioning the stories his mother had told him about her own mother, an Irishwoman born in Killarney who had come to England to live, but was "never really happy among the English" (394), Menen suggests, as does Said throughout his work, that language is always subjective and always contexted. He once more collocates, stratifies, relativizes, and aggregates: like South Asians, the Irish, too, have been othered by the English, who in turn are othered by the Indians. The very dynamics of fractiousness are shown to be conjunctive because they are ubiquitous manifestations of human will and human effort, part of the affirmation of the self and the identification of the Other which entail that "neither the term Orient nor the concept of the West has any ontological stability" (Said xvii). The Christian nuns at the prestigious convent school in India attended by the daughters of the prosperous Sikh community are defamiliarized by the diasporic Shauna Singh Baldwin through an iconoclastic analogy evocative of the geological distortions produced in the earth's crust when one tectonic plate collides with and slides under an adjacent plate moving in the other direction. The female narrator in the short story "Jassie" observes: "were they not the several wives of a dead and risen God? And how were they different from the thousand consorts of Krishna, the God of the Hindus?" (Baldwin 151). The devious subduction, complete with the etymological resonances of sub (underground) and ductio (lead), effectively leads readers to recall that nuns are (multiple) brides of Christ, and that the Mother Superior is indeed a form of "senior-most wife" (151). Building upon the analogy on a double level, both sacred and profane, Baldwin impels her international audience to collocate two major religions' manifestations of the divine, and thus justify and corroborate the legitimacy of a custom practised by one community - namely polygamy practised by the Sikhs - in spite of and even through the very set of religious beliefs which cause Christians to condemn the practice. 
The spectrum of works I have discussed deploy both horizontal and vertical distributional relations of discourse involving, on the one hand, combination, and on the other, substitution and layering. The displacements and palimpsestic superimpositions can be identified on sundry levels - semantic, stylistic, narrative, and intermedial. ${ }^{20}$ The textual spaces which they occupy illustrate the slippages between different worlds of lived and storied experience and the manner in which societal perceptions, practices, and predilections crisscross, carve, scrape and scour, deform, diffract, and interlock, in fruitful friction which mutually shapes and illuminates. It is useful to recall that the very concept subtending earth-moving tectonic processes involves construction, deriving from the Greek tekton or builder, and related to tekhne, skill or industry, without which the perceptible human world would be merely what Virginia Woolf in the neoplatonic Modernist vein playfully dismissed as "a vast upheaval of matter" (10). I am not going to align myself with the oversimplified position of the naïve Hungarian-Canadian character, Janet, in Shauna Singh Baldwin's story "Nothing Must Spoil This Visit," who is convinced that "people all over the world are the same, just with different languages, art, and music" (Baldwin 103). The Toronto production of Peggy Pickit Sees the Face of God did transpose the complacent frustrations of an idle Western married couple in Who's Afraid of Virginia Woolf onto a global stage. But when the white female character who has worked in fraught situations as a nurse in Africa finally cries out to the couple who has never left the West, "You have nooooo idea," ${ }^{21}$ the audience is brought to realize that there are things which can never be adequately represented, and that storied experience may not be apprehended by those who have not lived such trauma. The principal cultural divide has perhaps best been identified and synthesized by A. K. Ramanujan as the clash between context-sensitive and context-free societies, analogous to the two kinds of grammatical rules. In context-sensitive systems, behaviour and values are inherently relational, dependent on place, time, and social role, even on the nature of the listener. Context-free societies with egalitarian, democratic ideals rather paradoxically "espouse both the universal and the unique, insist that any member is equal to and like any other in the group. Whatever his context - birth, class, gender, age, place, rank, etc. - a man is a man for all that" (Ramanujan 434, original stress). Globalization may well be tied to what Ramanujan identified as modernization in India, notably as "a movement from the context-sensitive to the context-free in all realms: an erosion of contexts" (436). It may be useful to return spiral-fashion to the exemplar of cultural subduction I alluded to in my introduction, namely the iconic work One Thousand and One Nights revived and reinvented for the stage by renowned Lebanese novelist Hanan al-Shaykh, dramatized and directed by the theatre and opera director from Sussex, Tim Supple, commissioned by the Toronto-based festival Luminato, produced by London-based Dash Arts, and created and performed (in English, Arabic, and French with surtitles) by actors, musicians, and designers from across the Arabic-speaking world. Do the processes of its production and subsequent participation in the Edinburgh

20. See how, using Anita Desai's novel In Custody as a test case, I investigate transnational writing rooted in different canons and their belief systems which have always migrated, mixed, and mutated (in The Faces of Carnival). And the intermedial overlapping which I discussed almost two decades ago (in "Canadian Generic Boundary Crossing") is but a tip of the iceberg in current forms of artistic production, inhabited by sophisticated electronic and visual technologies.

21. Toronto Luminato performance, June 2010. 
International Festival and then its world tour celebrate the powerful influence of Eastern cultural and artistic traditions on the cultural landscapes of the West or contribute to an erosion of contexts? Or do they admirably illustrate the very possibility of reconciling construction and erosion?

\section{Marta DVORAK, Université Sorbonne Nouvelle - Paris 3}

\section{Works Cited}

Austen, Jane. Pride and Prejudice. 1813. London: Dent, 1970.

—. Sense and Sensibility. 1811. London: Richard Bentley \& Son, 1882.

BAKHTIN, Mikhail. The Dialogic Imagination. Austin: Texas UP, 1981.

- " "Marxism and the Philosophy of Language." The Rhetorical Tradition: Readings from Classical Times to the Present. Ed. Patricia Bizell and Bruce Herzberg. Boston: St. Martin's Press, 1990. 928-44.

BALDWIN, Shauna Singh. English Lessons and Other Stories. Fredericton, NB: Goose Lane, 1999.

BeCKetT, Samuel. The Trilogy: Molloy, Malone Dies, The Unnamable. London: Calder, 1994.

BoeHmer, Elleke. Colonial and Postcolonial Literatures: Migrant Metaphors. Oxford: Oxford UP, 1995.

Chaudhuri, Amit, ed. The Picador Book of Modern Indian Literature. London: Picador, 2001.

DASH, Michael. "Psychology, Creolization, and Hybridization." King 45-58.

DesAI, Anita. "The Indian Writer's Problems." Explorations in Modern Indo-English Fiction. Ed. R. K. Dawan. Delhi: Behri, 1982. Rpt. in Perspectives on Anita Desai. Ed. Ramesh K. Srivastava. Ghaziabad: Vimal Prakashan, 1984. n. p.

DHARWADKER, Vinay. "The Internationalization of Literatures." King 59-78.

DuTT, Michael Madhusudan. "The Indian Writer's Problems." Chaudhuri 3-7.

DvoraK, Marta. "Canadian Generic Boundary Crossing." Etudes Canadiennes/Canadian Studies 39 (1995): 205-16.

—. The Faces of Carnival in Anita Desai's In Custody. Paris: PUF, 2008.

—. "Frame-Breaking: 'neither separate nor complete nor important." Janet Frame Short Fiction issue, Commonwealth Essays and Studies 33.2 (Spring 2011): 137-49.

- " "Troping the Voice-Print: Derek Walcott's Rhetoric of Performance." Derek Walcott issue, Commonwealth Essays and Studies 28.2 (Spring 2006): 45-56.

ELiot, T. S. Collected Poems 1909-1962. London: Faber, 1975.

FAULKNER, William. Light in August. 1932. New York: Random, 1968.

FrAME, Janet. Janet Frame stories \& poems: The Lagoon and Other Stories, The Pocket Mirror. Auckland: Vintage/Random House New Zealand, 2004.

Fumagalli, Maria Cristina. The Flight of the Vernacular: Seamus Heaney, Derek W alcott, and the Impress of Dante. Cross Cultures 49. Amsterdam: Rodopi, 2001.

GANAPATHY-DorÉ, Geetha. "Shakespeare in Rushdie/Shakespearean Rushdie." Atlantis: Journal of the Spanish Association of Anglo-American Studies 31.2 (2009): 9-22.

GASCOIGNE, Bamber. The Great Moghuls. London: Robinson, 2002.

GoldsworTHY, Kerryn. "Fiction from 1900 to 1970." The Cambridge Companion to Australian Literature. Ed. Elizabeth Webby. Cambridge: Cambridge UP, 2000. 105-33.

HARrIS, Wilson. Selected Essays of Wilson Harris. Ed. Andrew Buy. London: Routledge, 1999.

HugGan, Graham. The Post-Colonial Exotic: Marketing the Margins. London: Routledge, 2001.

Jussawalla, Feroza F. Family Quarrels: Towards a Criticism of Indian Writing in English. New York: Peter Lang, 1985.

KAFKA, Franz. "The Metamorphosis." Die Verwandlung. Leipzig: Kurt Wolff Verlag, 1915.

KING, Bruce, ed. New National and Postcolonial Literatures: An Introduction. Oxford: Oxford Clarendon Press, 1996.

KING, Michael. Wrestling with the Angel: A Life of Janet Frame. Auckland: Viking, 2000.

KristeVA, Julia. Desire in Language: A Semiotic Approach to Literature and Art. 1977. Trans. T. Gora, A. Jardine. New York: Columbia UP, 1980.

MALOUF, Michael. "Dissimilation and Federation: Irish and Caribbean Modernisms in Derek Walcott's 'The Sea at Dauphin'." Comparative American Studies 8.2 (2010): 140-54.

Menen, Aubrey. Dead Man in the Silver Market. 1954. Chaudhuri 347-354.

RAMAnUJAN, A.K. "Is There An Indian Way of Thinking? An Informal Essay." 1989. Chaudhuri 420-37.

RutHerford, Jonathan. "The Third Space: An Interview with Homi Bhabha." Identity, Community, Culture, Difference. Ed. J. Rutherford. London: Laurence \& Wishart, 1998. 207-21. 
TAgore, Rabindranath. Selected Letters of Tagore. Ed. Krishna Dutta and Andrew Robinson. Foreword by Amartya Sen. Oriental Publications 53. Cambridge: U Cambridge P, 1997.

SAID, Edward. Orientalism. 1978. New York: Vintage, 1994.

Selvon, Sam. "The Cricket Match." 1957. The Oxford Book of Caribbean Short Stories. Ed. Stewart Brown and John Wickham. Oxford: Oxford UP, 1999. 91-5.

Synge, John Millington. The Playboy of the Western World and Riders to the Sea. 1907 and 1904 respectively. New York: Dover Thrift Editions, 1993.

Viswanathan, Gauri. "An Introduction: Uncommon Genealogies." Ariel: A Review of International English Literature 31.1 \& 2 (Jan-April 2000): 13-31.

WALCOTT, Derek. Collected Poems 1948-1984. London: Faber, 1992.

- " "Derek Walcott and E. A. Markham Read and Talk." Derek Walcott issue, Commonwealth Essays and Studies 28.2 (Spring 2006): 95-107.

—. "The Muse of History." What the Twilight Says: Essays. New York: Farrar, 1999. 36-64.

WaLSH, William. R. K. Narayan: Writers and their Works. London: British Council/Longman, 1971.

WoOLF, Virginia. The Mark on the Wall and Other Short Fiction. 1921. Oxford: Oxford UP, 2001. 